\title{
Kimberlites - from Mantle to Mine
}

\author{
Barbara H. Scott Smith \\ Scott-Smith Petrology Inc., Vancouver Canada, barbara@scottsmithpetrology.com
}

\section{Introduction}

Kimberlite is the term coined in the late $19^{\text {th }}$ century to describe "the matrix to diamond" when it was realised that the second South African diamond rush deposits were not alluvial but of volcanic origin. Today, kimberlite geology is the foundation of diamond mines. It is a descriptive science based on mega-, macro- and micropetrography which is communicated using words; a recent rationalisation of kimberlite terminology provides the words (Scott Smith et al. 2013, 2017). The resulting evidence is summarised here to provide a basis for improving our understanding of kimberlites, from the mantle to a mine, and to enhance the application of the results to diamond mining and research.

\section{Kimberlite}

Kimberlite, the main primary source of diamonds, now has a petrographic-based definition: 25 modal $\%$ anhedral olivine macrocrysts $(>1 \mathrm{~mm}$; Fig. 1$)$ and 25 modal \% euhedral olivine microcrysts $(<1$ $\mathrm{mm}$ ) set in a fine grained primary groundmass (Scott Smith et al. 2017). The definition is based on non-volcanic intrusive hypabyssal rocks from diamond mines which are the best representation of near surface pre-emplacement magmas. Recognising pre-eruption magmas as kimberlites (sensu stricto), although not straightforward, is key to focussed exploration and research; including other rock types (e.g. marginal kimberlites and related rocks) clouds our understanding of kimberlites.

\section{From the Mantle}

Kimberlites are a petrological clan with a narrow petrographic range (Fig. 1) suggesting the source of the initial melts is asthenospheric mantle (Fig. 2) with a composition persistent through space and time (50-1800 Ma.), a conclusion supported by diamond inclusion data. The olivine macrocrysts (Fig. 1) are xenocrysts incorporated during ascent of the melts through peridotitic subcratonic lithospheric mantle. The constant $\sim 25$ modal \% abundance of olivine macrocrysts (Fig. 1) indicates the maximum mantle cargo that a kimberlite magma can transport to surface, thus indicating the magmas with the greatest potential to contain macrodiamonds. Lamproites are a separate petrological clan which, in contrast to the kimberlite clan, encompasses a very wide petrographic range (Fig. 1) and derive from metasomatised lithospheric mantle (Fig. 2). The petrographic similarity and common petrogenesis of orangeites led Scott Smith et al. (2017) to propose they be renamed lamproite (var. Kaapvaal). Only the low proportion of lamproites that are olivine macrocryst-rich (Fig. 1) have the potential to carry macrodiamonds while olivine melnoites have a low potential. The diversity in abundance and type of other mantle xenocrysts including diamond entrained from the non-uniform lithospheric mantle shows that the melts ascend as discrete batches (Fig. 2).

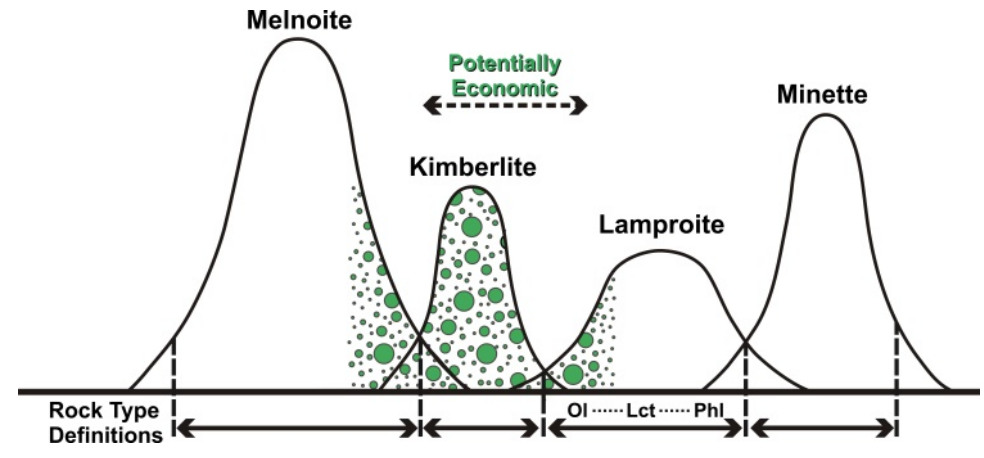

Figure 1: Schematic representation of petrographic-based definitions for kimberlite and related rocks. For each curve: (i) width of base indicates relative petrographic range within each petrological clan (Ol-olivine, Lctleucite, Phl-phlogopite denotes the wide range in lamproites); (ii) height reflects relative worldwide frequency; (iii) green circles mimic olivine macrocryst content, in particular the characteristic $25 \%$ of kimberlites. 
Kimberlite magmas rise from $>200 \mathrm{~km}$ reaching surface within $\sim 1$ day. Many features are explained by proposals that the starting melt is carbonatite-like and ascent is driven by assimilation of cratonic mantle orthopyroxene and then clinopyroxene which: (i) modifies the melt composition towards kimberlite; (ii) triggers exsolution of a low density volatile phase $\left(\mathrm{CO}_{2}+/-\mathrm{H}_{2} \mathrm{O}\right)$; (iii) reduces magma density and viscosity and increases buoyancy relative to lithospheric mantle, and (iv) causes rapid ascent of magma as dykes by crack-tip propagation with retention of $\sim 25$ modal $\%$ mantle cargo.

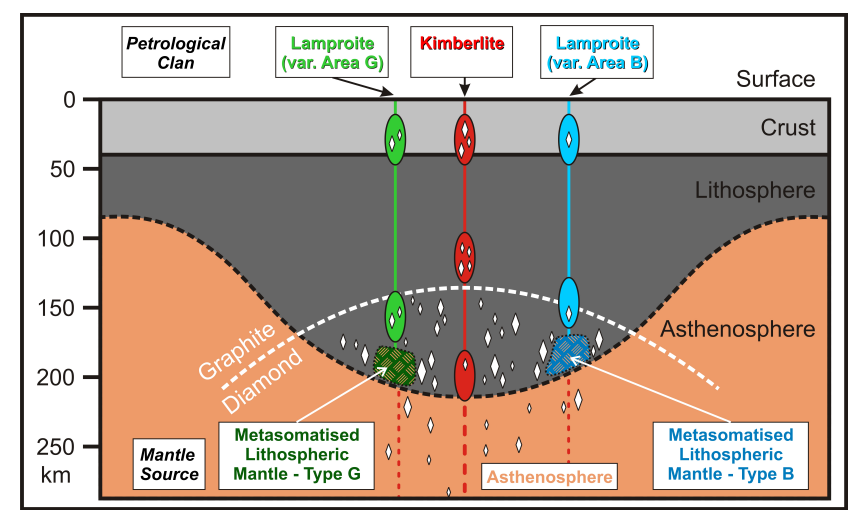

Figure 2: Schematic origin of primary sources of diamond: kimberlite and lamproite. White diamonds = non-uniform distribution of diamonds in the mantle. Red ovals = three separate batches of kimberlite melt ascending to surface with different diamond contents. Green and blue are contrasting types ( $\mathrm{G}$ and $\mathrm{B}$ ) of inhomogeneous (denoted by hashes) metasomatised lithospheric mantle that yield different areaspecific lamproite melts, e.g. lamproite (var. Area G or B).

Olivine microcrysts form another $\sim 25$ modal $\%$ of the magma that reaches near surface. Their remarkably uniform size $(<0.5-1 \mathrm{~mm})$ and euhedral habit indicate formation by similar melt crystallisation histories in each batch of magma prior to reaching near surface. Crystallisation of the olivine microphenocrysts which includes overgrowths on olivine xenocrysts may start at depths of $\sim 110 \mathrm{~km}$ as a consequence of pyroxene assimilation. Early primary $\mathrm{Cr}$-spinel can co-crystallise with olivine and early phlogopite can follow.

\section{To a Mine}

A single kimberlite body is formed by the separate emplacement of a number of discrete batches of magma (Fig. 2) in <1-2 Ma.; formation of a province spans <10-30 Ma.. All the emplacement products of a single batch of magma form one phase of kimberlite. Although broadly similar (50 modal \% olivine and 50 modal \% melt with minor spinel and phlogopite), each batch of kimberlite magma arriving at surface has had a different origin and ascent history resulting in variations in attributes such as the relative abundance of mantle xenoliths and xenocrysts (indicator minerals), groundmass minerals, crustal xenoliths and their reaction products. Such features are used to distinguish different phases of kimberlite within a single body. Applying predictive geology to their distribution is the foundation of the $3 \mathrm{D}$ geological models upon which diamond resource estimates are based because each phase of kimberlite has a different diamond content (grade and value). Each batch of magma also has a separate emplacement history during which the diamond content can be modified, sometimes on a scale important to economic assessments. It is important to note that one phase of kimberlite can include several textural types, or facies, resulting from variations within one overall emplacement event and the terms facies and phase are not synonymous.

Emplacement of kimberlite magma near surface forms two main types of body: volcanic pipes and intrusive sheets (Fig. 3). The latter involves the simple solidification of the melt portion of the magma through the crystallisation of fine grained groundmass spinel, perovskite, phlogopite, monticellite, apatite, serpentine and carbonate to form hypabyssal kimberlite (HK). When they reach surface, kimberlite magmas are unusual in that they retain significant amounts of volatiles. Volatile exsolution before and during emplacement can cause deuteric replacement of most components. Separation of an exsolving fluid phase from an ascending batch of magma can produce precursor emplacement events, in particular, the exploitation of pre-existing cracks. The formation of most volcanic pipes involves breakthrough to surface and eruption with volatile exsolution and expansion being important parts of the process. Primary pipe-infills form by magmatic processes; there is little evidence for phreatomagmatic processes being involved. 


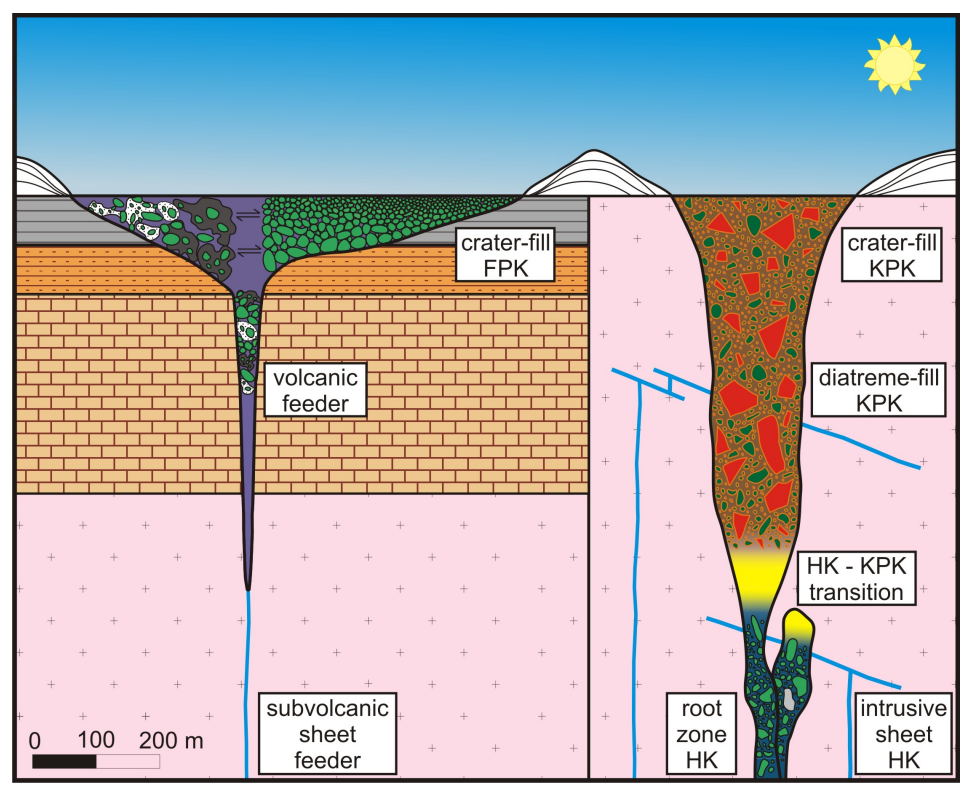

Figure 3: Schematic representation of the geology of the two end member types of pipes, their infills and associated features (after Fig. 4, Scott Smith 2008). Contrasting attributes include: the distribution of olivine (green) and xenoliths (red), the nature of the magmaclasts and intermagmaclast matrix as well as the association with HK. Relative to the pre-eruption magma (HK), changes in the distribution of any macrodiamonds present can be predicted using olivine macrocrysts.
Kimberlites include two distinct types of volcanic pipes and infills: Fort à la Corne-type and Kimberley-type pyroclastic kimberlites (FPK and KPK, respectively; Fig. 3). FPKs are broadly similar to subaerial basaltic pyroclastics. KPKs are unique to kimberlites with the diatreme-fill forming from subsurface intrusive texturallymodified magmatic systems (e.g. Mitchell and Scott Smith, this volume). The near surface country rock appears to control which pipe-type forms. The nature of associated coherent kimberlite also varies with pipetype. Intrusive $\mathrm{HK}$ occurs as sheets and root zones to diatreme-fill KPKs (Fig. 3). In FPKs coherent kimberlite occurs as extrusive lava lakes. Vacant pipes are infilled by diverse crater-rim resedimentation.

\section{Conclusions}

With the re-classification of orangeites as lamproites (var. Kaapvaal), primary sources of diamond include only two petrological clans: kimberlite and lamproite (Fig. 1). The relative proportions of olivine macrocrysts in the rocks (Fig. 1) reflects the thickness of cratonic lithospheric traversed during ascent (Fig. 2) and thus their diamond potential. Kimberlites are the main "matrix to diamond" because they are the deepest mantle-derived melts (Fig. 2). The key to interpreting all aspects of kimberlites at surface is understanding the nature of typical pre-emplacement parental magmas described in the petrological definition of kimberlite. Finding new kimberlite mines is based on discovering bodies formed from magmas that match the definition (Fig. 1). Deviations from the definition usually indicate magmas with a lower diamond potential (Fig. 1) whereas minor differences within the definition are used to identify separate phases of kimberlite forming a body. Understanding the nature of pre-emplacement kimberlite magmas also results in more meaningful interpretation of emplacement products and processes (Fig. 3) and the potential to optimise exploration, evaluation and mining strategies. Further, research on kimberlites from mantle-to-mine and the economic implications thereof are most relevant if focussed on the "matrix of diamond", in other words well constrained kimberlite samples derived from mines with detailed supporting datasets.

\section{References}

Scott Smith BH (2008) Canadian kimberlites: Geological characteristics relevant to emplacement. Journal of Volcanology and Geothermal Research, 174, p. 9-19.

Scott Smith BH, Nowicki TE, Russell JK, Webb KJ, Mitchell RH, Hetman CM, Harder M, Skinner EMW, Robey JV (2013) Kimberlite Terminology and Classification. Proceedings of the $10^{\text {th }}$ International Kimberlite Conference. Special Issue of the Journal of the Geological Society of India, Volume 2, 1-17. Springer India.

Scott Smith BH, Nowicki TE, Russell JK, Webb KJ, Mitchell RH, Hetman CM, Robey JV (2017) A Glossary of Related Terms. Scott-Smith Petrology Inc., Vancouver, Canada. 